\title{
Techno-Economic Study of Linear Fresnel Solar Thermal Power Plant in Algeria
}

\author{
Hani Beltagy \\ Département de Génie \\ Mécanique \\ Université Mouloud Mammeri \\ Tizi Ouzou, Algeria \\ hani.beltagy@gmail.com
}

\author{
Sofiane Mihoub \\ Annexe de Sougueur, Faculté de \\ Sciences de la Matière \\ Université de Tiaret \\ Tiaret, Algeria
}

\author{
Hamid Ajdad \\ Département énergétique \\ Ecole Nationale Supérieure \\ d'Arts et Métiers \\ Meknes, Maroc
}

\author{
Noureddine Said \\ Centre de Développement des \\ Energies Renouvelables, CDER \\ Bouzaréah, Alger, Algérie
}

\begin{abstract}
The objective of the present work is to characterize a power plant with concentrator of Fresnel on various Algerian sites (Sahara). These sites were chosen for comparison by moving the power plant in the Algerian sites: Hassi-R'mel, Tamanrasset, BéniAbbes, and El Oued. A technico-economic study was made to determine the various characteristics of the power plant. This study is carried out through a simulation in the hourly scale: it concerns the insolation, the system 'field', and the 'receiving' system. The results of the simulation are represented on annual average. Annual energy production and the cost per $\mathrm{kWh}$ are evaluated, the technico-economic results are also estimated for the same sites, and the results are compared for the purpose of site classification.
\end{abstract}

Keywords- solar energy; solar concentrator mirrors; thermoelectric plants, Fresnel solar thermal power plants; Technoeconomic performance.

\section{INTRODUCTION}

Energy consumption worldwide is increasing rapidly due to increasing global population and industrialization processes in many countries [1]. Consequently, considerable efforts are being made to effect a gradual transition from systems based on fossil fuels to those based on renewable energies. In Algeria, it has been announced in the renewable energy and energy efficiency program a new motivated CSP projects. In this ambitious program, CSP plants represent about $70 \%$ of the total power projects to be installed [2, 3]. Moreover CSP can be a competitive source of bulk power in peak and inter mediate loads in the sunniest regions by 2020 , and of base load power by 2025 2030 [4].

Renewable energies are at the heart of the 2011-2030 energy development program adopted by the Government in 2015. The program includes development of photovoltaic and wind energy, the use of waste biomass, cogeneration, and geothermal. It also postpones solar thermal (CSP) to 2021. To meet national market need over the 2015-2030 period $22000 \mathrm{MW}$ is required, of which 2000MWis to come from solar thermal and it is to be expanded to be more than $4500 \mathrm{MW}$ by 2030 .

Concentrated solar power (CSP) is unique among solar energy technologies because it has been operating commercially at utility-scale since 1985, and it generates electricity with a thermal power cycle similar to that used in conventional fossil fuel-fired power plants [5].To extract electricity from solar radiation, the power plants use the technology of solar concentration. CSP technologies now constitute feasible commercial options for large scale power plants aswell as for smaller electricity and heat generating devices.

The main objective in this present work is to perform a theoretical modeling of a solar power plant equipped with concentrator of Fresnel, in such a way of being able to simulate it in various Algerian sites and to adapt it to the weather conditions of Algeria. This simulation will let the reader compare the annual deliverability of a 5 MWe power plant in different chosen sites and to evaluate the price of $\mathrm{kWh}$ product (L.E.C) for each situation: HassiR'mel for the Center, Béni-Abbes in the West, El Oued for the East and Tamanrasset for the South.

\section{METHODS}

SAM (solar advisor model) The System Advisor Model (SAM) is a performance and financial model designed to facilitate decision making for people involved in the renewable energy industry [6]. SAM makes performance predictions and cost of energy estimates for grid-connected power projects based on installation and operating costs and system design parameters that you specify as inputs to the model, it is developed by NREL 
and it uses TRNSYS as a transient simulation code [6]. This work methodology is divided in this way:

- Collecting data: economical and meteorological data.

- Simulation: using SAM with entering all collected data and try to use all avail-able information.

- Discussing the results: to know and to decide the validity of the project.

The simulation is divided into two major parts, the technical and the economic one.

The solar power plant chosen for this study is a 5 MWe Fresnel concentrator plant which is technically similar to the German Novatec solar plant set up in Calasparra site in Spain [7].

All the characteristics of the said power plant are depicted in the following table [7].

TABLE I. Power plant characteristics

\begin{tabular}{|c|c|c|c|c|c|}
\hline \multicolumn{2}{|c|}{ Mirror field } & \multicolumn{2}{|c|}{ Receiver } & \multicolumn{2}{|c|}{ Power block } \\
\hline $\begin{array}{l}\text { Area of the } \\
\text { solar field }\end{array}$ & $\begin{array}{c}21571 \\
\mathrm{~m}^{2}\end{array}$ & $\begin{array}{c}\text { Tube } \\
\text { diameter }\end{array}$ & $\begin{array}{c}0.07 \\
\mathrm{~m}\end{array}$ & $\begin{array}{l}\text { Efficiency of } \\
\text { the plant }\end{array}$ & $35 \%$ \\
\hline $\begin{array}{l}\text { Length of } \\
\text { the solar } \\
\text { field }\end{array}$ & $80.6 \mathrm{~m}$ & $\begin{array}{l}\text { Receiver } \\
\text { diameter }\end{array}$ & $0.6 \mathrm{~m}$ & $\begin{array}{c}\text { Inlet } \\
\text { temperature }\end{array}$ & $140{ }^{\circ} \mathrm{C}$ \\
\hline $\begin{array}{c}\text { Net } \\
\text { opening } \\
\text { area }\end{array}$ & $\begin{array}{c}18489 \\
\mathrm{~m}^{2}\end{array}$ & $\begin{array}{l}\text { Distance } \\
\text { between the } \\
\text { reflector } \\
\text { and } \\
\text { absorber }\end{array}$ & $7 \mathrm{~m}$ & $\begin{array}{c}\text { Outlet } \\
\text { temperature }\end{array}$ & $270{ }^{\circ} \mathrm{C}$ \\
\hline $\begin{array}{l}\text { Width of } \\
\text { the field }\end{array}$ & $\begin{array}{c}16.56 \\
\mathrm{~m}^{2}\end{array}$ & & & $\begin{array}{l}\text { Power output } \\
\text { of the } \\
\text { generator }\end{array}$ & $5 \mathrm{MWe}$ \\
\hline $\begin{array}{l}\text { Reflector } \\
\text { surface }\end{array}$ & $\begin{array}{c}513.6 \\
\mathrm{~m}^{2}\end{array}$ & & & & \\
\hline $\begin{array}{l}\text { Module } \\
\text { length }\end{array}$ & $44.8 \mathrm{~m}$ & & & & \\
\hline $\begin{array}{l}\text { Length of } \\
\text { the } \\
\text { reflector }\end{array}$ & $0.75 \mathrm{~m}$ & & & & \\
\hline
\end{tabular}

\section{RESULTS AND DISCUSSION}

Figure 1 shows the hourly variations of the different techno-economical parameters for the different locations and based on the results obtained with the Software SAM. The different techno-economical parameters are mainly the annual direct irradiation IRDA, the annual energy produced, the Levelized Electricity Cost (LEC), the turnover (DA), and the number of years to recover the investment.

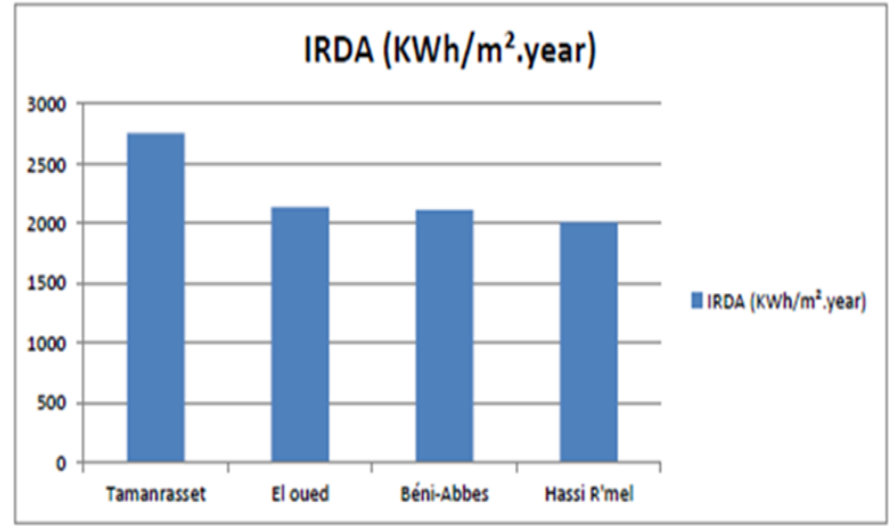

(a)

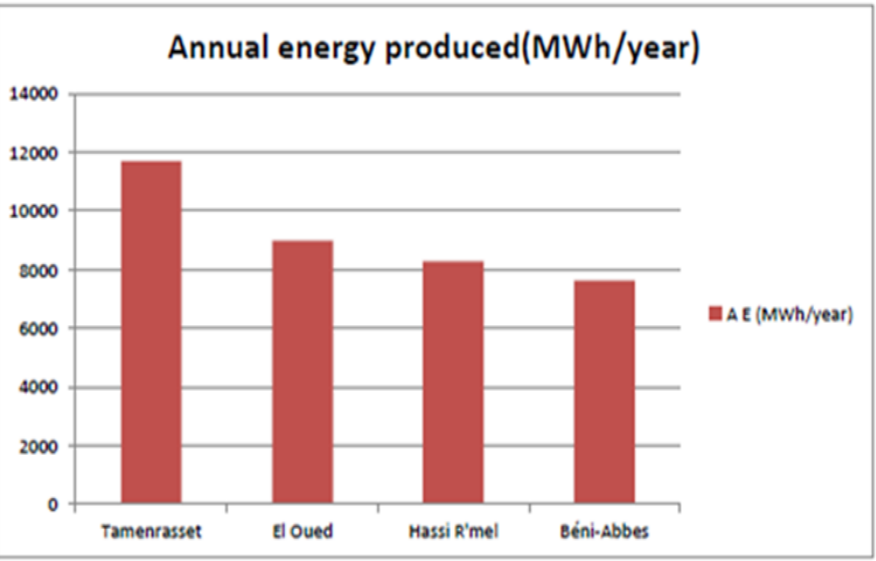

(b)

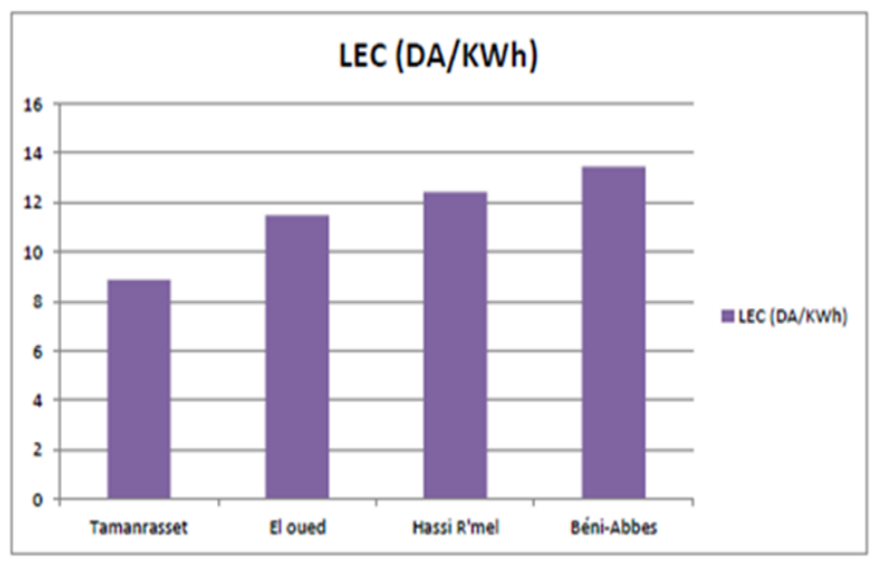

(c) 


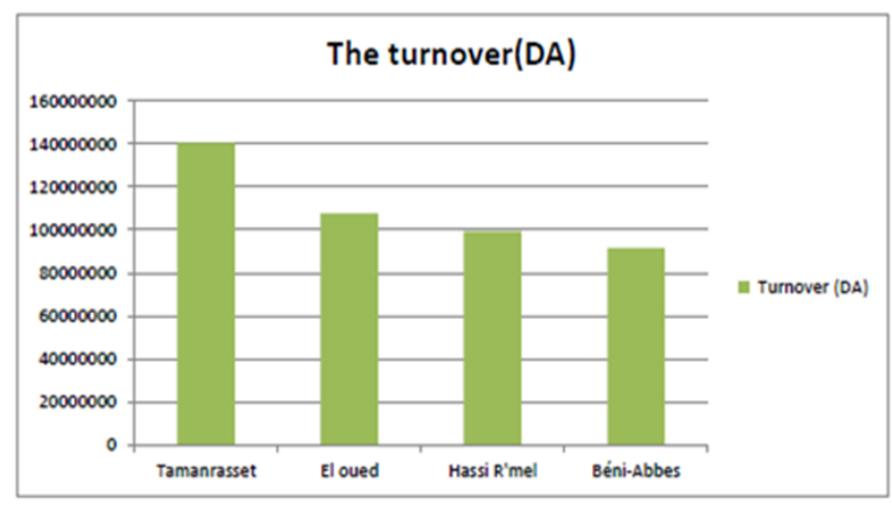

(d)

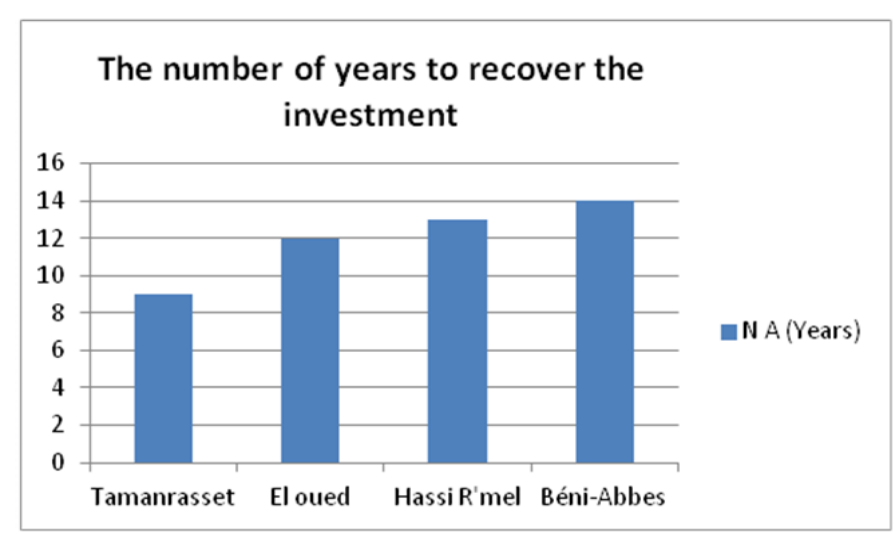

(e)

Fig. 1. Variation of the techno-economical performance for the 4 sites.

The annual direct irradiations of the sites of Tamanrasset, El Oued, Béni-Abbess, and Hassi R' mel are respectively 2759.4 $\mathrm{kWh} / \mathrm{m}^{2}$ a year, $2137 \mathrm{kWh} / \mathrm{m}^{2}$ a year, $2114 \mathrm{kWh} / \mathrm{m}^{2}$ a year and $2008.4 \mathrm{kWh} / \mathrm{m}^{2}$ a year. Therefore, Tamanrasset has the most mattering solar field with an annual direct irradiation which exceeds $2500 \mathrm{~kW} / \mathrm{m}^{2}$ a year, which returns this site the most favorable to this type of technology of solar concentration.

For the annual produced energy, one can notice that Tamanrasset appears at first also. It has a more important energy than the other sites; it is followed by El Oued, of Béni-Abbes then HassiRmel. These sites offer an annual energy respectively equal to $11704.152 \mathrm{MWh}, 8981.695 \mathrm{MWh}, 8280.325 \mathrm{MWh}$ and 7631.6 MWh.

Concerning the LEC (Levelized electricity cost), which indicates the cost updated by the electricity; the most profitable site is the one which has a weak LEC. Thus according to the Figure 1-c, the site which has a weak LEC is Tamanrasset, followed by El Oued, HassiR'mel, then Béni-Abbes, for values respectively of $8.86 \mathrm{DA} / \mathrm{kWh}, 11.47 \mathrm{DA} / \mathrm{kWh}, 12.42 \mathrm{DA} /$ $\mathrm{kWh}$, et13.45 DA / kWh.

The figure of affair (business) calculated for the four considered sites are obtained by multiplying the annual energy produced by the cost updated by the kWh (4DA). This gives the values of 46.816.608 DA for the site of Tamanrasset, 35.926.780 DA for the site of El Oued, 33.121.300 DA for HassiR'mel site, and 30.526.400 DA for the site of Béni-Abbes estimated at the rate of $4 \mathrm{DA}$ the $\mathrm{kWh}$ (cost practised by Sonelgaz). If one take into account the law of help suggested by the government in the power production by solar means (that is 3 times the above values) [8] It returns us to recalculate the figure of affair for 12 $\mathrm{DA}$ the $\mathrm{kWh}$ and the results are the following ones: 140.449 .824 DA for the site of Tamanrasset, 107.780.340 DA for the site of El Oued, 99.363.900 DA for Hassi R' mel's site, and 91.579.200 DA for the site of Béni-Abbes.

Finally so that the power plant gets back its investment, the number of years of functioning which it is necessary to get back the capital cost of the power plant should be calculated. This parameter is obtained by dividing the total cost of the power plant which is 1.287.295.660 DA by the obtained figure of affair or for $4 \mathrm{DA}$ the $\mathrm{kWh}$ or for $12 \mathrm{DA}$, if one takes into account incentive measures. The obtained results follow those of the produced energy, as well as the figure of affair. The most profitable site is the one of Tamanrasset, followed by that of El Oued, then HassiRmel, and Béni-Abbes, with respectively durations of 27 years, 35years, 38 years, 42 years,

at the rate of $4 \mathrm{DA}$ the $\mathrm{kWh}$. If the calculation is done for 12DA the $\mathrm{kWh}$ the results are 9 years, 12years, 13years, and 14years. Here, one can clearly see the importance of the application of the decree " feed in tariff " of the ministry of the energy which allows to sell to a triple price (prize) the $\mathrm{kWh}$, by taking Tamanrasset for example, from 10th year the income of the power plant is $100 \%$ earnings (gains).

\begin{tabular}{|c|c|c|c|c|}
\hline $\begin{array}{c}\text { Selected } \\
\text { locations }\end{array}$ & HassiR'mel & Tamanrasset & $\begin{array}{c}\text { Béni- } \\
\text { Abbés }\end{array}$ & El Oued \\
\hline $\begin{array}{c}\text { Annual radiation } \\
\text { (kWh/m².year) }\end{array}$ & 2008.4 & 2759.4 & 2114 & 2137 \\
\hline $\begin{array}{c}\text { Net annual } \\
\text { energy (MWh) }\end{array}$ & 8280 & 11704 & 7631 & 8981 \\
\hline LEC (DA/kWh) & 12.42 & 8.86 & 13.45 & 11.47 \\
\hline $\begin{array}{c}\text { Turnover for the } \\
\text { kWh 4 DA }\end{array}$ & 33121300 & 46816608 & 30526400 & 35926780 \\
\hline $\begin{array}{c}\text { Turnover for the } \\
\text { kWh 12 DA }\end{array}$ & 99363900 & 140449824 & 91579200 & 107780340 \\
\hline $\begin{array}{c}\text { Gain for the kWh } \\
4 \text { DA }\end{array}$ & 2594900 & 16290208 & 0 & 5400380 \\
\hline $\begin{array}{c}\text { Gain for the kWh } \\
12 \text { DA }\end{array}$ & 7784700 & 48870624 & 0 & 16201140 \\
\hline $\begin{array}{c}\text { Percentage of } \\
\text { gain (\%) }\end{array}$ & 7.83 & 34.7 & 0 & 15 \\
\hline $\begin{array}{c}\text { Number of years } \\
\text { of profitability } \\
\text { (4DA) }\end{array}$ & 38 years & 27 years & 42 years & 35 years \\
\hline $\begin{array}{c}\text { Number of years } \\
\text { of profitability } \\
\text { (12DA) }\end{array}$ & 13 years & 9 years & 14 years & 12 years \\
\hline
\end{tabular}




\section{Conclusion}

This work concerned a comparative study of the technoeconomical performance of a Fresnel concentrator based solar power plant for different locations in Algeria: HassiR'mel, Tamanrasset, Béni-Abbés, and El Oued. The different technoeconomical parameters investigated are mainly the annual direct irradiation, the annual energy produced, the Levelized Electricity Cost, the turnover, and the number of years to recover the investment. Software SAM was used to perform the calculations supported by weather conditions related to the Algerian sites.It is shown that the most promising site for application of the power plant is the site of Tamanrasset with a net annual energy of 11 $704 \mathrm{MWh}$, a levelized electricity cost of $8.86 \mathrm{DA} / \mathrm{kWh}$, a turnover at 4 DA $\mathrm{kWh}$ of 46816608 , a gain percentage of 34.7 $\%$, and a number of years of profitability of 27 years.

\section{Acknowledgements}

The authors are grateful to Dr. Said Noureddine from CDER (Renewable Energy Development Center, Algeria) for his constant guidance and critical review in improving the manuscript.

\section{References}

[1] Ghoneim. A.A., A.M. Mohammedein and Kandil M. Kandil, Performance Analysis of Parabolic Trough Collector in Hot Climate ; British Journal of Applied Science \& Technology, vol 4,ํำ14, pp. 2038-2058, 2014.

[2] Renewable energy policy network for the 21stcentury (REN21), (2012). Global status report. [Online]. Available: http:/ /www.map. ren21.net/ GSR/ GSR2012_low.pdfS.

[3] Abbas M, KasbadjiMerzouk N, Techno economic study of solar thermal power plants for centralized electricity generation in Algeria. 2nd international symposium on environment-friendly energies and applications, EFEA . pp. 17983, 2012.

[4] Ministry of Energy and Mines, Renewable energy and energy efficiency program (2011). www.mem-algeria.org.

[5] S. J. Wagner, E. S. Rubin, Economic implications of thermal energy storage for concentrated solar thermal power. Renewable Energy, Elsevier, pp1-15, 2012.

[6] Paul Gilman, Solar Advisor Model User Guide for Version 2.0; August 2008.

[7] Web site: http //www.Novatec solar.com. Consulted February 2017.

[8] Décret exécutif $n^{\circ}$ 04-92 du 4 Safar 1425 correspondant au 25 mars 2004 relatif aux coûts de diversification de la production d'électricité. Ministère de l'énergie et des mines mars. 